\title{
COL3A1 Gene Product
}

National Cancer Institute

\section{Source}

National Cancer Institute. COL3A1 Gene Product. NCI Thesaurus. Code C143054.

A protein encoded by the COL3A1 gene. 